\title{
Trimeric G proteins modulate the dynamic interaction of PKAll with the Golgi
}

\section{complex}

\author{
María Esther Martín*, Josefina Hidalgo*, Francisco M. Vega and Angel Velasco‡ \\ Department of Cell Biology, Faculty of Biology, University of Seville, 41012-Seville, Spain \\ *The first two authors contributed equally to this study \\ ¥Author for correspondence (e-mail: avelasco@cica.es)
}

Accepted 2 September; published on WWW 3 November 1999

\section{SUMMARY}

The Golgi complex represents a major subcellular location of protein kinase A (PKA) concentration in mammalian cells where it has been previously shown to be involved in vesicle-mediated protein transport processes. We have studied the factors that influence the interaction of PKA typeII subunits with the Golgi complex. In addition to the cytosol, both the catalytic $(\mathrm{C} \alpha)$ and regulatory (RII $\alpha)$ subunits of PKAII were detected at both sides of the Golgi stack, particularly in elements of the cis- and trans-Golgi networks. PKAII subunits, in contrast, were practically absent from the middle Golgi cisternae. Cell treatment with either brefeldin $\mathrm{A}, \mathrm{AlF}_{4}^{-}$or at low temperature induced PKAII dissociation from the Golgi complex and redistribution to the cytosol. This suggested the existence of a cycle of association/dissociation of PKAII holoenzyme to the Golgi. The interaction of purified RII $\alpha$ with Golgi membranes was studied in vitro and found not to be affected by brefeldin A while it was sensitive to modulators of heterotrimeric $\mathrm{G}$ proteins such as $\mathrm{AlF}_{4}^{-}, \mathrm{GTP} \gamma \mathrm{S}, \beta \gamma$ subunits and mastoparan. RII $\alpha$ binding was stimulated by recombinant, myristoylated $\mathrm{G} \alpha_{\mathrm{i} 3}$ subunit and inhibited by cAMP. Pretreatment of Golgi membranes with bacterial toxins known to catalyze ADP-ribosylation of selected G $\alpha$ subunits also modified RII $\alpha$ binding. Taken together the data support a regulatory role for Golgi-associated $G \alpha$ proteins in PKAII recruitment from the cytosol.

Key words: Protein Kinase A, Golgi complex, Trimeric G protein

\section{INTRODUCTION}

The protein kinase A (PKA) holoenzyme is a heterotetramer composed of a regulatory $(\mathrm{R})$ subunit dimer that binds two catalytic (C) subunits. Binding of cAMP to each $\mathrm{R}$ subunit results in dissociation of the $\mathrm{C}$ subunits, which then become free and catalytically active to phosphorylate a variety of protein substrates on serine or threonine residues present in the consensus sequence Arg-Arg-X-Ser/Thr or Lys-Arg-X-XSer/Thr. Depending on the particular ligand that triggers PKA activation, enzymes, transcription factors, and membranebound ion channels can be phosphorylated (Taylor et al., 1990).

In mammalian cells, several isoforms of both $\mathrm{C}(\mathrm{C} \alpha, \mathrm{C} \beta$, $\mathrm{C} \gamma)$ and $\mathrm{R}(\mathrm{RI} \alpha, \mathrm{RI} \beta, \mathrm{RII} \alpha, \mathrm{RII} \beta)$ subunits exist that differ in subcellular localization, kinetic characteristics, and sensitivity to inhibitors and cAMP. Two holoenzyme subtypes named type I and type II are formed by the combination of either RI or RII with $\mathrm{C}$ subunits. While type I holoenzyme is predominantly cytosolic a significant proportion of the type II holoenzyme is found associated with subcellular structures such as the centrosome, actin cytoskeleton, microtubules, endoplasmic reticulum, plasma membrane, mitochondria, and peroxisomes (Dell'Acqua and Scott, 1997). Association occurs throughout the specific interaction of RII subunits with particular A kinase-anchoring proteins (AKAPs). It is believed that AKAPs help to organize the cellular responses to an increase in cAMP intracellular concentration by bringing together PKA enzyme and substrates (Colledge and Scott, 1999). Tethering of PKA to a particular subcellular location in close proximity to its substrates may explain the phosphorylation of selective protein targets despite the broad specificity exhibited by this kinase (Pawson and Scott, 1997).

Several reports indicate that PKA regulates vesiclemediated protein transport processes along the exocytic (Hansen and Casanova, 1994; Pimplikar and Simons, 1994; Mostov and Cardone, 1995; Jilling and Kirk, 1996; Muñiz et al., 1996; Zegers and Hoekstra, 1997; Valenti et al., 1998) and endocytic (Bradbury and Bridges, 1992; Eker et al., 1994; Hansen and Casanova, 1994; Goretzki and Mueller, 1997) pathways. PKA is associated with the Golgi complex in a number of cell types (Nigg et al., 1985b; De Camilli et al., 1986; Griffiths et al., 1990; Dohrman et al., 1996; Feliciello et al., 1996). We have recently shown that PKA enzymatic activity is required for the production of constitutive transport vesicles from the trans-Golgi network (Muñiz et al., 1997). An 85-kDa Golgi membrane protein with properties of AKAP has also been identified (Rios et al., 1992). Taken together these studies suggest a pivotal role for PKA activity in Golgi structural organization and function. Golgi association, on the other hand, is not 
permanent. Following an increase in cAMP intracellular concentration the free $\mathrm{C}$ subunits redistribute to the nucleus while $\mathrm{R}$ subunits remain associated with the Golgi (Nigg et al., 1985a; Dohrman et al., 1996). Moreover, RII $\alpha$ has been recently shown to dissociate from the Golgi-centrosomal region during mitosis (Keryer et al., 1998). Also, in thyroid cells RII $\beta$ redistributed from the Golgi to the cytosol following Ras or protein kinase $\mathrm{C}$ activation (Feliciello et al., 1996). In this report, we have investigated the factors that influence the interaction of PKAII subunits with the Golgi membranes. Results obtained in cells incubated with brefeldin A (BFA) or at low temperature indicate that PKAII holoenzyme continuously cycles between the cytosol and the Golgi. This cycle seems to be modulated by heterotrimeric $\mathrm{G}$ proteins present in the Golgi membranes. Although considerable attention has received the influence of these trimeric $\mathrm{G}$ proteins in Golgi structural organization (Hidalgo et al., 1995; Denker et al., 1996; Jamora et al., 1997; Yamaguchi et al., 1997) and transport activities (Donaldson et al., 1991; Stow et al., 1991; Bomsel and Mostov, 1992; Colombo et al., 1992; Ktistakis et al., 1992; Leyte et al., 1992; Schwaninger et al., 1992; Pimplikar and Simons, 1993; Helms et al., 1998), little is known about the way these modulators exert their actions. In this respect, our results suggest that Golgi trimeric $G$ proteins control PKAII recruitment from the cytosol which in turn could determine protein export from this organelle.

\section{MATERIALS AND METHODS}

\section{Reagents}

A plasmid containing the full length clone for N-terminal His-tag murine RII $\alpha$ was a kind gift from Dr S. Taylor (University of California, San Diego, CA). Protein was expressed in Escherchia coli BL21 (DE3) cells according to the method of Cheng et al. (1998) and purified with Talon (Clontech, Palo Alto, CA) metal affinity resin according to the manufacturer's instructions. Protein was eluted with $0.5 \mathrm{M}$ imidazole in $20 \mathrm{mM}$ Tris- $\mathrm{HCl}, \mathrm{pH} 8.0,100 \mathrm{mM} \mathrm{NaCl}$, dialyzed extensively against PBS containing $1 \mathrm{mM}$ PMSF and PBS/10\% glycerol, and concentrated to $2-3 \mathrm{mg} / \mathrm{ml}$ final protein concentration. Antibodies against bacterially expressed His-tagged murine RII $\alpha$ and $\mathrm{C} \alpha$ were raised in rabbits. Antisera were subjected to ammonium sulfate precipitation and affinity purification on recombinant protein coupled to activated Sepharose 4 (Pharmacia, Uppsala, Sweden). Western blot analysis showed that the specificity of these antibodies was similar to that of commercial antibodies raised against amino acid sequences from the carboxy terminus of human $\mathrm{C} \alpha$ and RII $\alpha$ proteins (Santa Cruz Biotechnology, CA). Rabbit polyclonal antibody against an N-terminal peptide of mouse RII $\beta$ was purchased from Biomol (Plymouth Meeting, PA) and tested on immunoblots containing total cellular proteins prepared from rat brain. G1/133 (Linstedt and Hauri, 1993), CTR453 (Bailly et al., 1989), and 1D3 mouse monoclonal antibodies against giantin, centrosome, and KDEL were kindly provided by Dr H. P. Hauri (Biozentrum, Basel, Switzerland), Dr M. Bornens (CNRS, Paris, France), and Dr S. Fuller (European Molecular Biology Laboratory, Heidelberg, Germany) respectively. Transducin $\beta \gamma$ subunits were a gift from Dr Y. K. Ho (University of Illinois at Chicago, IL). BFA, ATP, GTP $\gamma$ S, cAMP and M3A5 mouse monoclonal antibody against $\beta$-COP were purchased from Sigma Chemical Co. (St Louis, MO). Goat anti-rabbit or anti-mouse IgG secondary antibodies conjugated to either fluoresceine or rhodamine were from TAGO (Burlingame, CA). Protein A (Pharmacia) was coupled to $8 \mathrm{~nm}$ colloidal gold particles according to the method of
Slot and Geuze (1985). Bacterial toxins and rat, recombinant $\mathrm{G} \alpha_{\mathrm{i} 3}$ were acquired from Calbiochem (San Diego, CA). Mastoparan was obtained from Fluka (Buchs, Switzerland).

\section{Cell culture}

COS-7 cells were maintained in high glucose DMEM supplemented with $10 \%$ fetal calf serum, $2 \mathrm{mM}$ glutamine, $50 \mathrm{U} / \mathrm{ml}$ penicillin, and $50 \mu \mathrm{g} / \mathrm{ml}$ streptomycin.

\section{Cytosol, Golgi, and microsomal preparations}

Bovine brain cytosol was obtained as described previously (Hidalgo et al., 1995). Cytosol was dialyzed against several changes of $25 \mathrm{mM}$ Hepes-KOH, pH 7.2, $25 \mathrm{mM} \mathrm{KCl}, 2.5 \mathrm{mM} \mathrm{MgCl}_{2}$; aliquots $(9-10 \mathrm{mg}$ protein $/ \mathrm{ml}$ ) were frozen in liquid nitrogen, and stored at $-80^{\circ} \mathrm{C}$. Golgi stacks were prepared from rat liver according to the method of Slusarewicz et al. (1994). The preparation was enriched 80- to 90-fold over the initial homogenate as judged by immunodetection of mannosidaseII. Golgi membranes were incubated on ice with $3 \mathrm{M} \mathrm{KCl}$ for 10 minutes, recovered by centrifugation $(12,000 \mathrm{~g}, 20$ minutes) on a $2 \mathrm{M}$ sucrose cushion, resuspended in $25 \mathrm{mM}$ Hepes- $\mathrm{KOH}$, $\mathrm{pH} 7.2$, $25 \mathrm{mM} \mathrm{KCl}, 2.5 \mathrm{mM} \mathrm{MgCl}$, at $1 \mathrm{mg} / \mathrm{ml}$, frozen in liquid nitrogen, and stored at $-80^{\circ} \mathrm{C}$. To prepare total microsomal membranes, COS7 cells were resuspended in a small $(2-3 \mathrm{ml})$ volume of ice-cold 0.1 $\mathrm{M}$ phosphate buffer, $\mathrm{pH} 7.2$, containing $1 \mathrm{mM}$ PMSF, $5 \mathrm{mM}$ benzamidine, $100 \mu \mathrm{g} / \mathrm{ml}$ soybean trypsin inhibitor, $20 \mu \mathrm{g} / \mathrm{ml}$ aprotinin, and $10 \mu \mathrm{g} / \mathrm{ml}$ of each leupeptin, antipain, and pepstatin A. They were homogenized by several passes throughout a ball-bearing homogenizer. The postnuclear supernatant was centrifuged at 100,000 $g$ in a TLA-100 ultracentrifuge and both the supernatant containing soluble proteins and the microsomal pellet were processed for SDSPAGE and immunoblotting.

\section{Rll $\alpha$ binding assay}

To monitor binding of cytosolic RII $\alpha$, Golgi membranes $(20 \mu \mathrm{g})$ were incubated with $3 \mathrm{mg} / \mathrm{ml}$ bovine brain cytosol, $1 \mathrm{mM} \mathrm{ATP}$, and $1 \mathrm{mM}$ GTP in a final volume of $50 \mu \mathrm{l}$ of $25 \mathrm{mM}$ Hepes-KOH, $\mathrm{pH} 7.2,25$ $\mathrm{mM} \mathrm{KCl}, 2.5 \mathrm{mM} \mathrm{MgCl} 2,1 \mathrm{mM}$ DTT (assay buffer). Alternatively, $20 \mu \mathrm{g}$ Golgi membranes were incubated with $0.5 \mathrm{mg} / \mathrm{ml}$ recombinant RII $\alpha$ in $50 \mu \mathrm{l}$ assay buffer. Incubation in both cases was carried out in siliconized microfuge tubes at $37^{\circ} \mathrm{C}$ for 15 minutes. Samples were diluted with $1 \mathrm{ml}$ ice-cold assay buffer and transferred to new microfuge tubes. Membranes were recovered by centrifugation $(12,000 \mathrm{~g}, 20$ minutes $)$ at $4^{\circ} \mathrm{C}$ on a $30 \mu \mathrm{l} 2 \mathrm{M}$ sucrose cushion, transferred to new microfuge tubes, rinsed twice with assay buffer, and finally resuspended in electrophoresis sample buffer.

\section{Electrophoresis and immunoblotting}

Reduced proteins were resolved in $12.5 \%$ acrylamide gels run in the presence of SDS according to the method of Laemmli (1970). They were then transferred to Immobilon-P (Millipore, Bedford, MA) membranes which were blocked with $5 \%$ dry milk/1\% Tween-20 in TBS, pH 8.0, and incubated with primary antibody diluted in the same buffer. Membranes were revealed by enhanced chemiluminiscence (Amersham, Buckinghamshire, UK) according to the instructions of the manufacturer. Bands were quantitated by scanning densitometry.

\section{Immunocytochemistry}

Cells cultured on round glass coverslips were used for immunofluorescence. They were fixed in 3\% formaldehyde, prepared from paraformaldehyde, in PBS, rinsed with PBS, and incubated in $0.5 \%$ bovine serum albumin $/ 0.05 \%$ saponin in PBS (PBS/BSA/saponin). Cells fixed in cold methanol were used to localize centrosome with CTR453 antibody. Antibodies were diluted in PBS/BSA/saponin. Incubation with antibodies was performed in a moist chamber at $37^{\circ} \mathrm{C}$ for 30 minutes. Coverslips were rinsed with PBS and mounted in PBS/glycerol. For immunogold labeling, cells were fixed for 1 hour in $3 \%$ formaldehyde $/ 0.01 \%$ glutaraldehyde in 
$0.1 \mathrm{M}$ phosphate buffer, $\mathrm{pH}$ 7.4. They were rinsed with PBS, infiltrated with $2.3 \mathrm{M}$ sucrose/20\% polyvinylpyrrolidone, and frozen in liquid nitrogen. Cryosections were recovered on nickel grids and rinsed extensively with PBS first and then with PBS/BSA. Incubation with primary antibodies and Protein A-gold complexes, both diluted in PBS/BSA, was performed in a moist chamber at room temperature for 2 hours and 1 hour, respectively. Sections were stained with a mixture (1:9) of 3\% uranyl acetate and $2 \%$ methyl cellulose. For quantitation, micrographs were printed at a final magnification of $\times 70,000$. Five random selected Golgi areas were analysed for each protein. The trans side of the Golgi stack was identified by the presence of clathrin-coated buds. Each compartment was delimited with an electronic pen that automatically converted the length of the closed outline into surface area. The number of gold particles within each compartment was counted and used to calculate the density of labeling.

\section{Binding of [ $\left.{ }^{35} \mathrm{~S}\right] \mathrm{GTP} \gamma \mathrm{S}$ to $\mathrm{G} \alpha_{\mathrm{i} 3}$}

100-200 ng of $\mathrm{G}_{\mathrm{i} 3}$ were incubated for 1 hour at $37^{\circ} \mathrm{C}$ in $50 \mu \mathrm{l}$ of 25 $\mathrm{mM}$ Hepes, $\mathrm{pH}$ 7.0, $50 \mathrm{mM}$ potassium acetate, $2.5 \mathrm{mM}$ magnesium acetate, containing $1 \mathrm{mM}$ EDTA, $0.5 \mathrm{mM}$ ATP, $1 \mathrm{mg} / \mathrm{ml} \mathrm{BSA}, 2 \mu \mathrm{M}$ GTP $\gamma \mathrm{S}, 250$ pmoles $\left[{ }^{35} \mathrm{~S}\right] \mathrm{GTP} \gamma \mathrm{S}(1000 \mathrm{Ci} / \mathrm{mmol})$. The reaction was stopped with $1 \mathrm{ml}$ cold buffer and the sample rapidly filtered through nitrocellulose. Filters were rinsed with $5 \times 1 \mathrm{ml}$ ice-cold buffer and dried before liquid scintillation counting.

\section{RESULTS}

\section{Golgi PKAll localization}

Since different cell lines differ in the type of $\mathrm{R}$ subunit associated with the Golgi (Rios et al., 1992; Dohrman et al., 1996; Keryer et al., 1998) we first determined the presence of either RII $\alpha$ or RII $\beta$ in COS-7 cells. Western blots containing total cellular proteins were incubated with antisera raised against either $\mathrm{C} \alpha$, RII $\alpha$ or RII $\beta$ (Fig. 1A). A single band of molecular mass $\sim 53 \mathrm{kDa}$ was recognized by antibody against RII $\alpha$ (Fig. 1A, lane 2) while no specific immunoreactivity was detected with anti-RII $\beta$ antibody (Fig. $1 \mathrm{~A}$, lane 3 ) or preimmune sera (not shown). Anti-C $\alpha$ antibody reacted with a $40 \mathrm{kDa}$ protein which is the expected size for the catalytic subunit (Fig. 1A, lane 1). In fixed cells processed for indirect immunofluorescence both antibodies strongly stained the perinuclear Golgi area identified with a monoclonal antibody against the resident Golgi protein giantin (Linstedt and Hauri, 1993) (Fig. 2). In addition, a diffuse, cytoplasmic staining was observed with both antibodies. However, neither $\mathrm{C} \alpha$ nor RII $\alpha$ colocalized completely with giantin. Staining with this Golgi marker was more restricted to the perinuclear area than that of the PKAII subunits. Long membrane processes emerging from the Golgi and reaching the peripheral cytoplasm were frequently observed with both anti-C $\alpha$ and anti-RII $\alpha$ antibodies (see Fig. 8A). Also, both antibodies stained one or two perinuclear brilliant spots. Staining with the monoclonal antibody CTR453 (Bailly et al., 1989) indicated that these structures corresponded to the centrosome (see Fig. 4). That both PKAII subunits existed in soluble and membrane-associated forms was confirmed by subcellular fractionation. Comparison by immunoblotting of cytosolic and microsomal proteins indicated that almost $55 \%$ of RII $\alpha$ and $30 \%$ of $\mathrm{C} \alpha$ were found associated with microsomal membranes (Fig. 1B). These values are probably underestimated since cells were
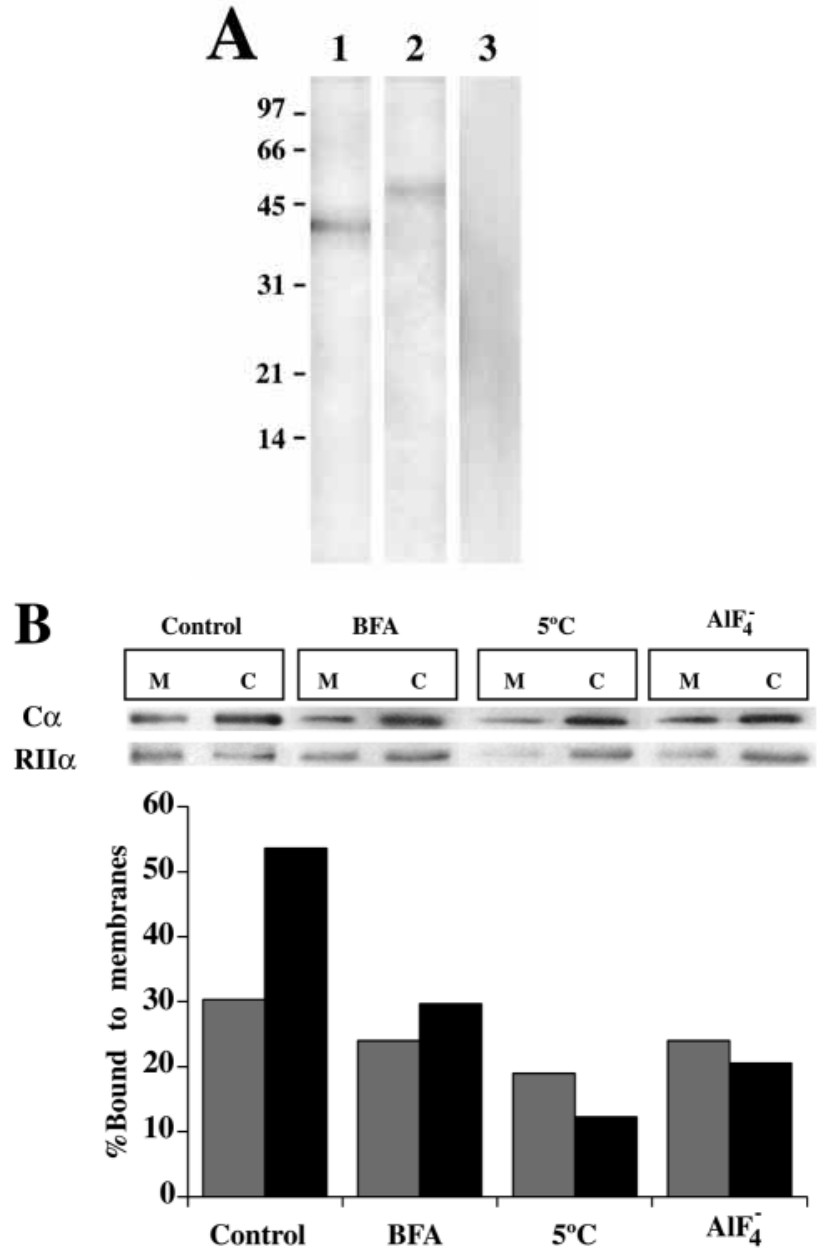

Fig. 1. Immunodetection of PKAII subunits in COS-7 cells. (A) Total cellular proteins $(15 \mu \mathrm{g}$ per lane) were resolved by SDS-PAGE and analyzed by immunoblotting with antibodies against $\mathrm{C} \alpha$ (lane 1), RII $\alpha$ (lane 2), and RII $\beta$ (lane 3). Molecular mass markers are indicated in $\mathrm{kDa}$. (B) Cells were incubated for 30 minutes at $37^{\circ} \mathrm{C}$ with medium containing either no addition (control), $10 \mu \mathrm{M}$ BFA or $50 \mu \mathrm{M} \mathrm{AlCl}_{3}$ and $30 \mathrm{mM} \mathrm{NaF}\left(\mathrm{AlF}_{4}^{-}\right)$. Alternatively, cells incubated for 30 minutes at $5^{\circ} \mathrm{C}$ were also processed. They were homogenized and fractionated to obtain total microsomal and cytosolic proteins. These were analyzed by immunoblotting ( $7 \mu \mathrm{g}$ per lane) with anti$\mathrm{C} \alpha$ and anti-RII $\alpha$ antibodies. Results derived from band quantitation by scanning densitometry are shown.

homogenized on ice and membranes centrifuged at $4^{\circ} \mathrm{C}$ (see below). Both proteins were also localized to the same Golgi compartments by immunogold labeling. These included both sides of the Golgi complex with little staining of the medial

Table 1. Quantitation of the immunogold labeling of PKAII subunits in the Golgi area of COS-7 cells

\begin{tabular}{lcc}
\hline & $\mathrm{C} \alpha$ & $\mathrm{RII} \alpha$ \\
\hline Cis tubulo-vesicular structures & $597 \pm 66(n=47)$ & $427 \pm 120(n=33)$ \\
The cis-most cisterna & $167 \pm 78(n=6)$ & $143 \pm 28(n=8)$ \\
$2-3$ medial cisternae & $27 \pm 30(n=10)$ & $37 \pm 22(n=13)$ \\
The trans-most cisterna & $152 \pm 21(n=8)$ & $78 \pm 45(n=9)$ \\
TGN elements & $376 \pm 42(n=85)$ & $743 \pm 140(n=50)$
\end{tabular}

Data (mean \pm s.e.m.) indicate number of gold particles $/ \mu \mathrm{m}^{2}$. 

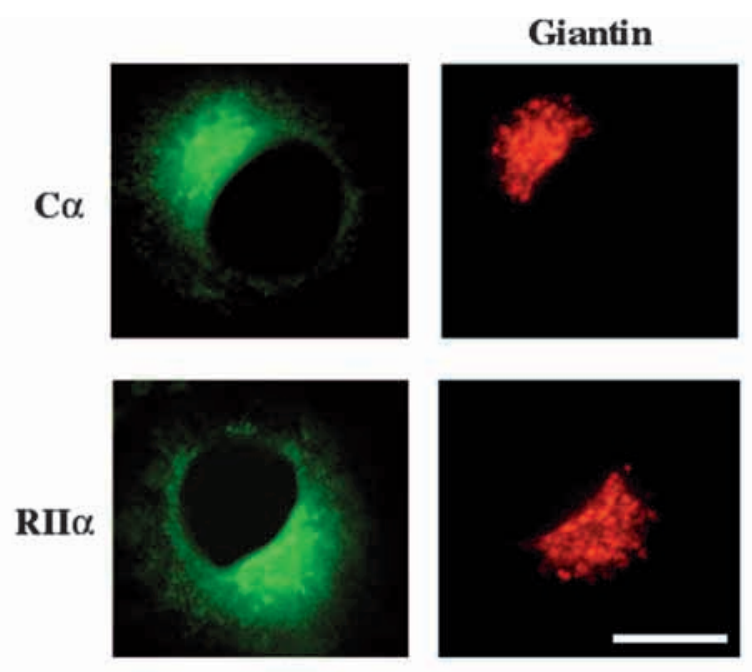

Fig. 2. Immunofluorescence localization of PKAII subunits. Cells were double stained with antibodies against either $\mathrm{C} \alpha$ or RII $\alpha$ subunits and the Golgi marker giantin. Bar, $18 \mu \mathrm{m}$.

cisternae (Fig. 3). 1-2 trans-Golgi cisternae and vesicles and tubular elements of the trans-Golgi network were heavily labeled. Also, vesicular-tubular structures close to the proximal, cis side of the Golgi stack were stained with both antibodies (Fig. 3). These observations were corroborated by quantitation of the density of labeling (Table 1). Labeling of the medial Golgi cisternae was thus similar to that of mitochondria $\left(9 \pm 7\right.$ gold particles $/ \mu \mathrm{m}^{2}$ with either anti-C $\alpha$ or anti-RII $\alpha$ antibody) or endoplasmic reticulum cisternae $(28 \pm 13)$ while it was negligible in the case of plasma membrane or the outer membrane of the nuclear envelope. Collectively, the data indicated that the trans- and cis-Golgi networks represent major subcellular locations of PKAII anchoring.

\section{Brefeldin A (BFA) effect}

BFA is known to interfere with the association of COPI coat protein complex to the Golgi membranes which in turn causes Golgi disassembly and redistribution to the endoplasmic reticulum (Klausner et al., 1992). We examined the fate of Golgi-associated PKAII during the course of BFA treatment. As shown in Fig. 4 the perinuclear staining pattern characteristic of RII $\alpha$ became diffuse and dispersed throughout the cytoplasm following incubation with $10 \mu \mathrm{M}$ BFA. This redistribution, however, was slower than that of $\beta$ COP, a component of COPI vesicle coat. Thus, $\beta$-COP redistribution itself took place during the first minute of BFA treatment while RII $\alpha$ redistribution became evident after 1015 minutes of incubation. Importantly, $\mathrm{C} \alpha$ also redistributed and with the same kinetics as RII $\alpha$ in the presence of BFA (not shown). In contrast, centrosome staining with either anti$\mathrm{C} \alpha$ or anti-RII $\alpha$ antibody was unaffected by BFA treatment (Fig. 4). Staining of the endoplasmic reticulum with an antibody against the KDEL sequence indicated that the BFA effect did not involve redistribution of the PKA subunits to this organelle. Thus, the reticular staining pattern obtained with anti-KDEL antibody was clearly distinguishable from the diffuse staining pattern obtained with either anti-C $\alpha$ or antiRII $\alpha$ (Fig. 4) antibody. This suggested that PKA subunits dissociated from the Golgi membranes during BFA treatment. Indeed, the amount of both $\mathrm{C} \alpha$ and RII $\alpha$ associated with microsomal membranes decreased following treatment with BFA (Fig. 1B).

To gain insight on the mechanism of PKAII redistribution we studied the in vitro association of cytosolic RII $\alpha$ to purified, high salt-washed rat liver Golgi membranes (Fig. $5)$. In this assay, RII $\alpha$ recruitment depended on the simultaneous presence of both cytosol and Golgi membranes and it was not inhibited by BFA. The amount of RII $\alpha$ incorporated to Golgi membranes was similar in the absence or in the presence of $500 \mu \mathrm{M}$ BFA while $\beta$-COP association was inhibited in samples incubated with BFA
Fig. 3. Immunogold localization of PKAII subunits within the Golgi area. Detection of $\mathrm{C} \alpha(\mathrm{A})$ and RII $\alpha$ (B) subunits. Labeling in both cases is mostly localized in vesicles and tubular elements at both sides of the Golgi stack, especially the trans-Golgi netwok (asterisks). Bars, $100 \mathrm{~nm}$.
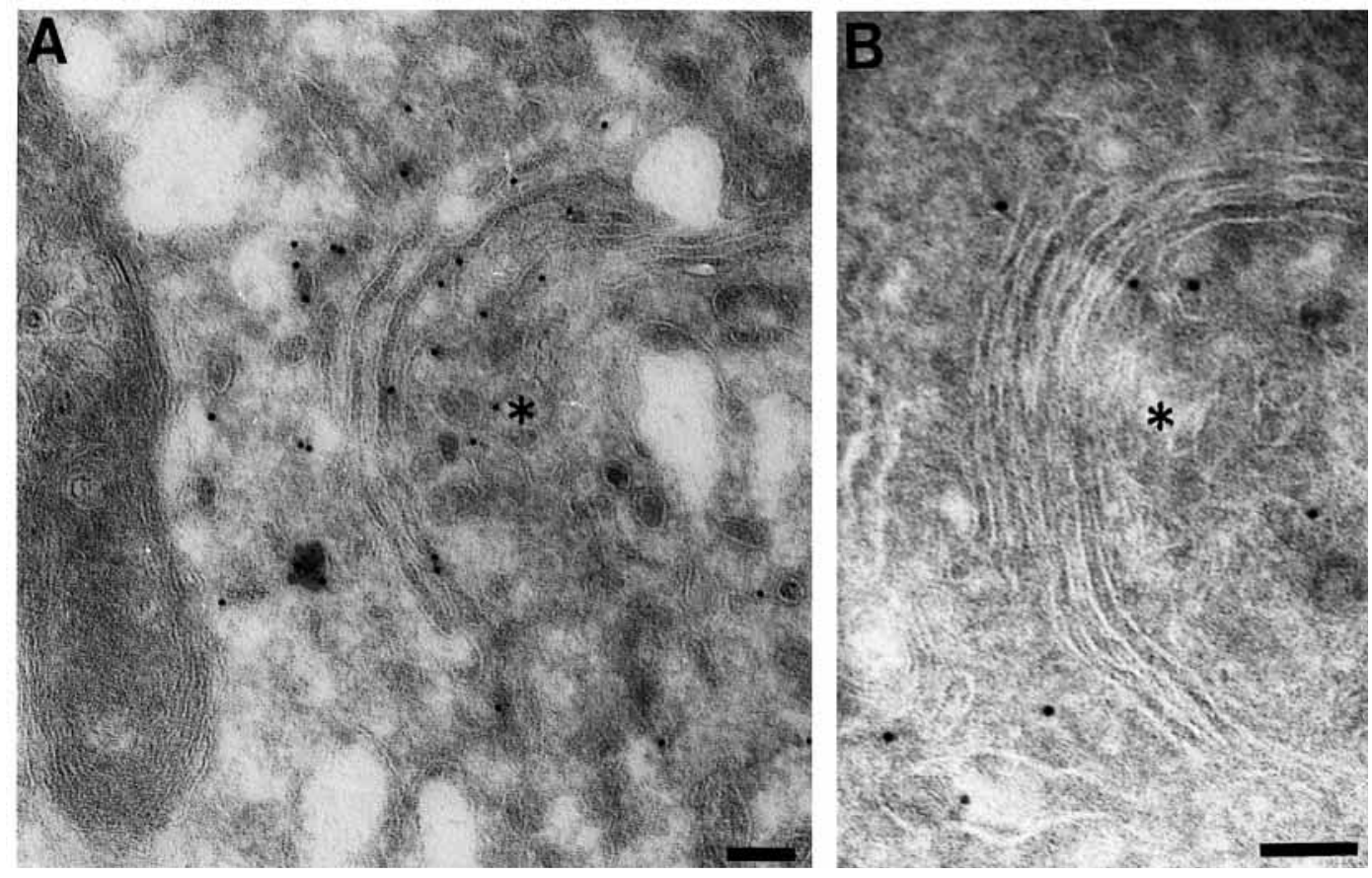
(Fig. 5). These results suggested that redistribution of PKAII subunits observed in cells exposed to BFA could be an indirect effect, derived from the absence of Golgi membranes which after some minutes of incubation with this agent would be mostly fused with the endoplasmic reticulum. To test this possibility we analyzed the
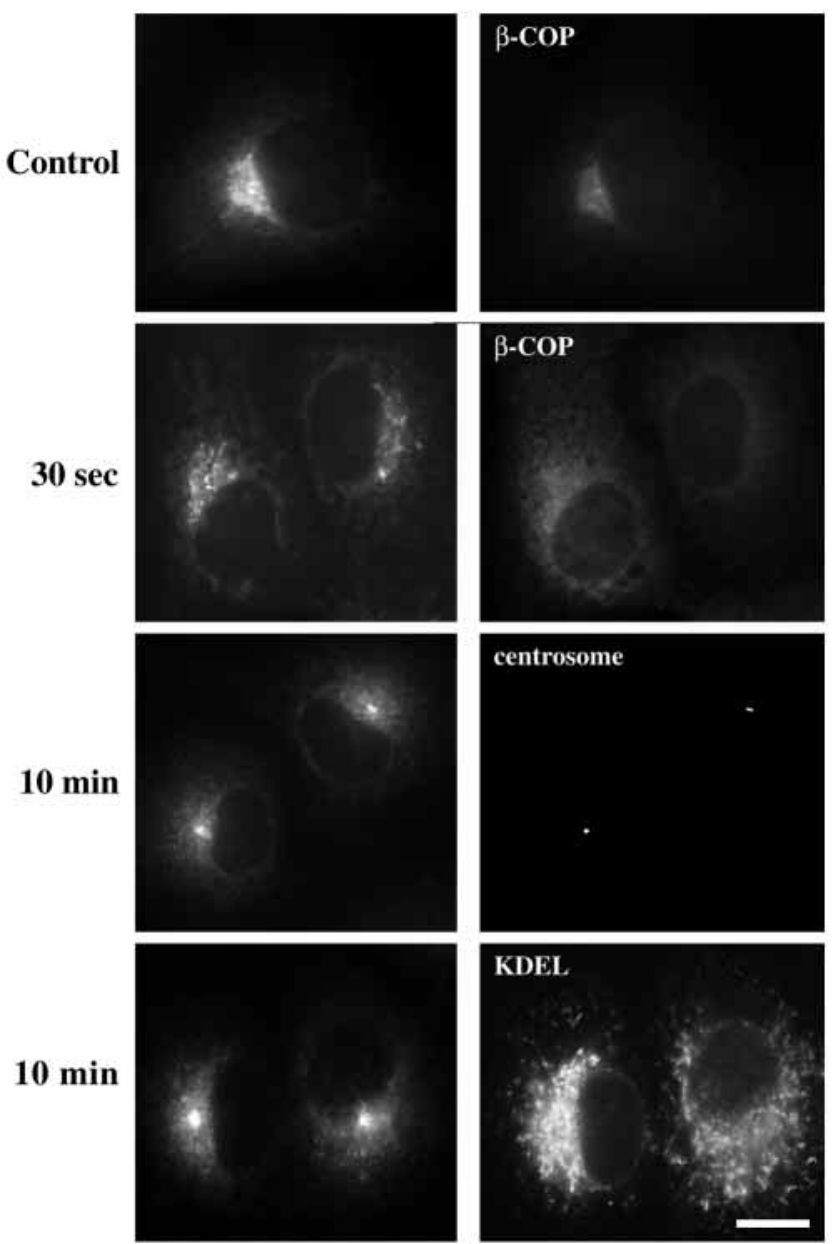

Fig. 4. Effect of BFA on RII $\alpha$ immunofluorescence localization. Cells were incubated or not (control) at $37^{\circ} \mathrm{C}$ with $10 \mu \mathrm{M}$ BFA for the indicated time periods before fixation and double staining with antibodies against RII $\alpha$ (left panels) and either $\beta$-COP, centrosome, or the KDEL sequence. Bar, $18 \mu \mathrm{m}$.

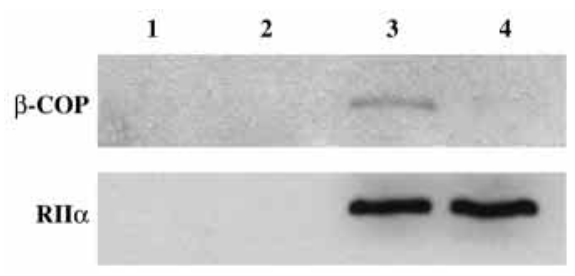

Fig. 5. Effect of BFA on RII $\alpha$ recruitment from cytosol. Golgi membranes $(20 \mu \mathrm{g})$ and cytosol $(3 \mathrm{mg} / \mathrm{ml})$ were incubated at $37^{\circ} \mathrm{C}$ for 15 minutes in the absence (lane 3) or presence of $500 \mu \mathrm{M} \mathrm{BFA}$ (lane 4). Membranes were rinsed and processed for SDS-PAGE and immunoblotting with antibodies against $\beta$-COP and RII $\alpha$. Samples lacking either cytosol (lane 1) or Golgi membranes (lane 2) were similarly processed.

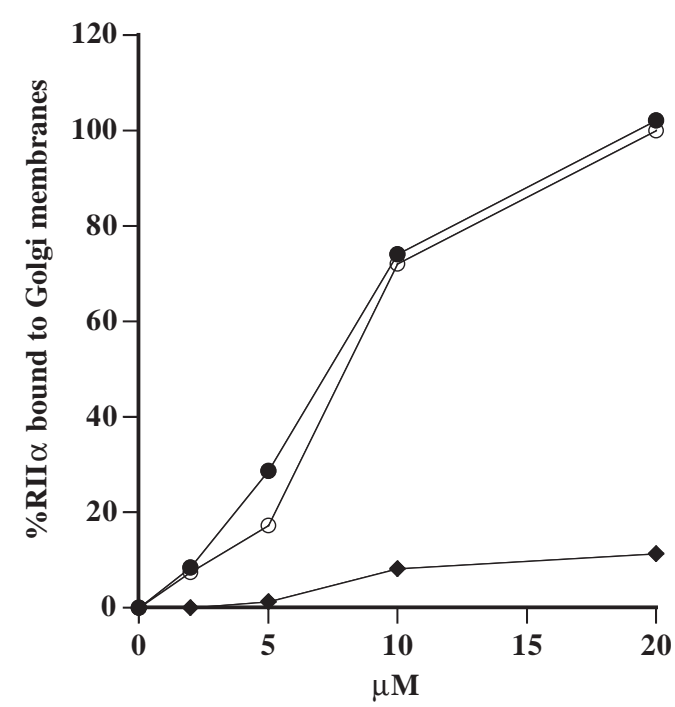

Fig. 6. Association of recombinant RII $\alpha$ to Golgi membranes. Golgi membranes $(20 \mu \mathrm{g})$ were incubated with the indicated concentrations of purified RII $\alpha$ for 15 minutes at $5^{\circ} \mathrm{C}(\diamond)$ or, alternatively, at $37^{\circ} \mathrm{C}$ in the absence (control, $\bigcirc$ ) or presence of $500 \mu \mathrm{M}$ BFA $(\mathbf{O})$. Membranes were rinsed and processed for SDS-PAGE and immunoblotting. The amount of RII $\alpha$ incorporated was quantitated by scanning densitometry.

association of pure, recombinant RII $\alpha$ to Golgi membranes (Fig. 6). In the continuous presence of Golgi membranes BFA did not affect RII $\alpha$ binding which at the different concentrations tested was comparable to that of control, untreated samples nonincubated with this agent (Fig. 6). Whereas these data exclude the possibility of BFA interfering directly with PKA recruitment they suggest that in vivo this holoenzyme continuously cycles between the cytosol and the Golgi membranes. This cycle would be interrupted in BFA-treated cells simply because of the absence of acceptor Golgi membranes.

\section{Low temperature effect}

Localization of PKAII to the Golgi complex depended on the temperature of incubation. Golgi immunofluorescence staining was less extensive in cells incubated at either $20^{\circ} \mathrm{C}$ or $15^{\circ} \mathrm{C}$ than in cells incubated at $37^{\circ} \mathrm{C}$ (Fig. $7 \mathrm{~A}$ ). Apparently, PKAII subunits gradually redistributed from the Golgi to the peripheral cytoplasm as temperature decreased. For instance, following incubation for 30 minutes at $5^{\circ} \mathrm{C}$ no Golgi staining was observed. Instead, both $\mathrm{C} \alpha$ (not shown) and RII $\alpha$ (Fig. 7A) subunits exhibited a cytoplasmic distribution although they remained concentrated at the centrosome. This observation correlated with a dramatic decrease in the amount of these proteins associated with microsomal membranes (Fig. 1B). Under these conditions, only $19 \%$ of $\mathrm{C} \alpha$ and $12 \%$ of RII $\alpha$ remained membraneassociated which in the case of RII $\alpha$ accounted for a 4.3 -fold decrease with respect to cells preincubated at $37^{\circ} \mathrm{C}$. At $5^{\circ} \mathrm{C}$ redistribution occurred rapidly and it did not involve changes in Golgi structural organization or dissociation of a peripheral Golgi protein such as $\beta$-COP (Fig. 7B). Interaction in vitro of RII $\alpha$ with Golgi membranes was 
A
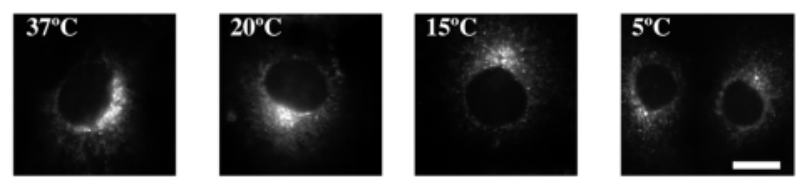

B

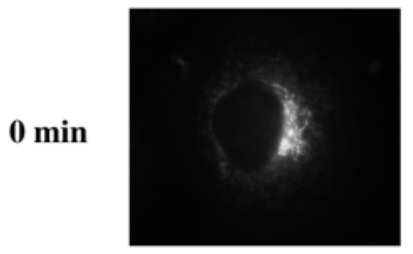

5 min

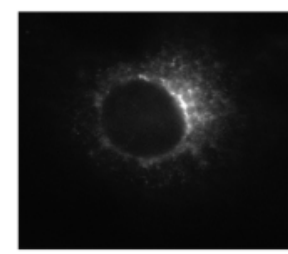

$15 \mathrm{~min}$
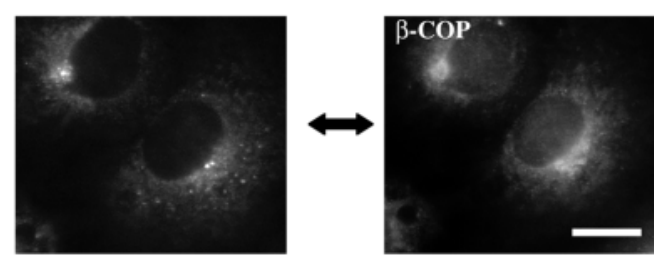

Fig. 7. Temperature-dependent redistribution of RII $\alpha$. Cells were incubated for 30 minutes at the indicated temperatures (A) or, alternatively, incubated at $5^{\circ} \mathrm{C}$ for the indicated time periods (B). They were fixed and processed for indirect immunofluorescence with anti-RII $\alpha$ antibody. Double staining with anti- $\beta$-COP is also shown in B. Bars, $18 \mu \mathrm{m}$.

inhibited at $5^{\circ} \mathrm{C}$ (Fig. 6) accounting for the redistribution observed in cells exposed to low temperature. These data therefore also support the existence of an itinerant cycle of PKAII between the Golgi and the cytosol.

\section{Modulation by trimeric $\mathrm{G}$ proteins}

The steady-state association of PKAII with the Golgi complex was not affected by treatment with $1 \mu \mathrm{M}$ of either staurosporine, a broad range protein kinase inhibitor, or okadaic acid, a serine/threonine phosphatase inhibitor, as well as with $30 \mu \mathrm{M} \mathrm{H}-89$, a specific PKA inhibitor. In addition, $50 \mu \mathrm{M}$ of either zinc chloride or pervanadate which are inhibitors of tyrosine phosphatases did not alter PKAII localization. In contrast, cells incubated with $\mathrm{AlF}_{4}^{-}$which activates trimeric $\mathrm{G}$ proteins (Kahn, 1991) showed dissociation of RII $\alpha$ from the Golgi complex but not from the centrosome (Figs 8A, 1B). $\mathrm{AlF}_{4}{ }^{-}$was formed by addition of $\mathrm{AlCl}_{3}$ and $\mathrm{NaF}$ to final concentrations of $50 \mu \mathrm{M}$ and $30 \mathrm{mM}$, respectively. When used alone at those concentrations, neither $\mathrm{AlCl}_{3}$ (Fig. 8A) nor NaF (not shown) alone modified PKAII localization. Interestingly, $\mathrm{AlF}_{4}{ }^{-}$inhibited reassociation of RII $\alpha$ to the Golgi following incubation at low temperature. As shown in Fig. 8B such a reassociation occurred efficiently at $37^{\circ} \mathrm{C}$ in the absence of $\mathrm{AlF}_{4}{ }^{-}$but not in the presence of this agent. Taken together these
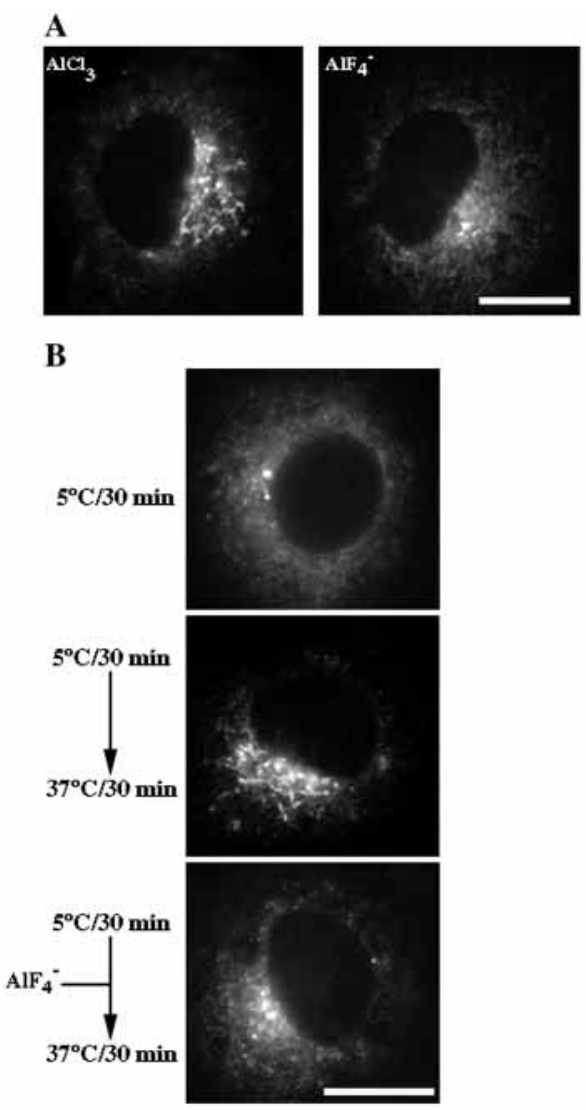

Fig. 8. Effect of $\mathrm{AlF}_{4}^{-}$on RII $\alpha$ immunofluorescence localization. (A) Cells were incubated at $37^{\circ} \mathrm{C}$ for 15 minutes with either $50 \mu \mathrm{M}$ $\mathrm{AlCl}_{3}$ alone or $50 \mu \mathrm{M} \mathrm{AlCl}_{3}$ and $30 \mathrm{mM} \mathrm{NaF}\left(\mathrm{AlF}_{4}^{-}\right)$before fixation and processing for indirect immunofluorescence. (B) Following incubation at $5^{\circ} \mathrm{C}$ for 30 minutes, cells were returned at $37^{\circ} \mathrm{C}$ and additionally incubated for 30 minutes in the presence or absence of $\mathrm{AlF}_{4}^{-}$. Bars, $18 \mu \mathrm{m}$.

observations pointed to a role of trimeric G proteins in RII $\alpha$ recruitment.

The effects of different modulators of trimeric $\mathrm{G}$ proteins were evaluated in a series of in vitro experiments (Fig. 9). First, the assay that reproduces the association of RII $\alpha$ to Golgi membranes was supplemented with agents that directly activate or inhibit trimeric G proteins (Fig. 9A). In agreement with the effect observed in vivo, $\mathrm{AlF}_{4}^{-}$decreased the incorporation of RII $\alpha$ to the Golgi to a $50-60 \%$ of the control value. A similar inhibition was observed with $25-100 \mu \mathrm{M}$ GTP $\gamma$, a poorly hydrolyzable analog of GTP. These two compounds, however, could potentially activate lowmolecular-mass, monomeric $\mathrm{G}$ proteins in addition to trimeric $\mathrm{G}$ proteins. A more specific reagent would be a complex of $\beta \gamma$ subunits purified from transducin. Free $\beta \gamma$ subunits are expected to bind and therefore inactivate $\mathrm{G} \alpha$ subunits (Bomsel and Mostov, 1992). Association of RII $\alpha$ was stimulated by 2fold with 5-10 $\mu \mathrm{M} \beta \gamma$ (Fig. 9A).

Whereas these results suggested a negative regulatory role of trimeric $\mathrm{G}$ proteins on RII $\alpha$ incorporation, additional data indicated that particular $\mathrm{G} \alpha$ proteins might play a stimulatory role. Thus, addition of recombinant, myristoylated $\mathrm{G} \alpha_{\mathrm{i} 3}$ subunit at nanomolar concentrations 
A

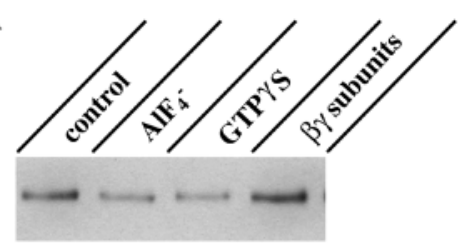

B

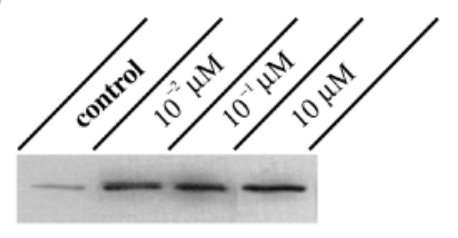

C

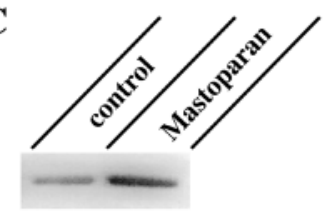

D
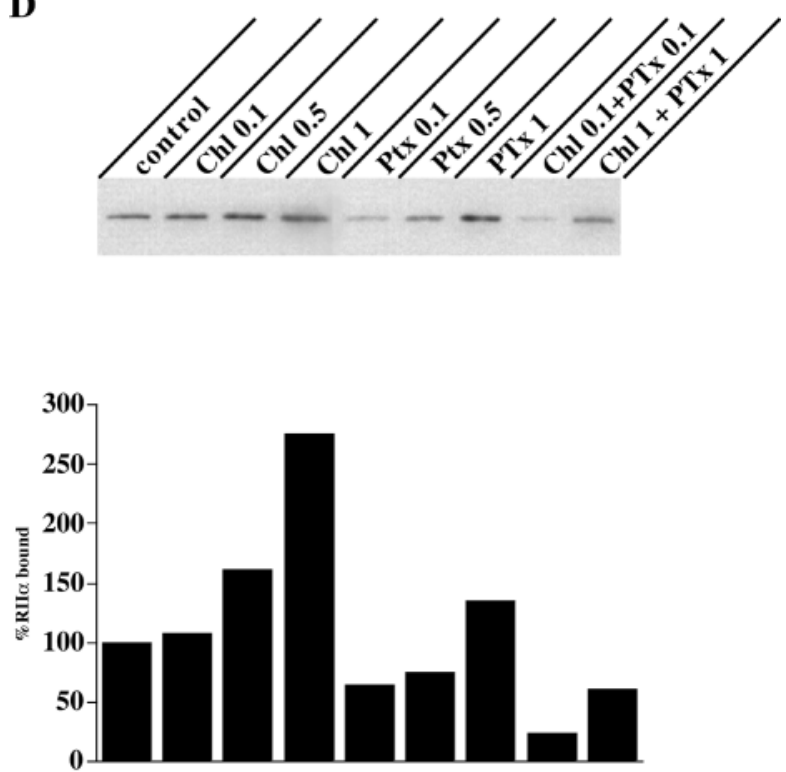

Fig. 9. Effects of trimeric $\mathrm{G}$ proteins modulators on RII $\alpha$ recruitment. Golgi membranes $(20 \mu \mathrm{g})$ were incubated for 15 minutes at $37^{\circ} \mathrm{C}$ with $10 \mu \mathrm{M}$ recombinant RII $\alpha$ and processed as described in Fig. 6. (A) The incubation medium contained no further addition (control) or, alternatively, was supplemented with $50 \mu \mathrm{M} \mathrm{AlCl} 3$ and $30 \mathrm{mM} \mathrm{NaF}\left(\mathrm{AlF}_{4}^{-}\right), 50 \mu \mathrm{M} \mathrm{GTP} \gamma \mathrm{S}$, or $10 \mu \mathrm{M}$ transducin $\beta \gamma$ subunits. (B) The incubation medium contained or not (control) the indicated concentrations of pure, myristoylated Gai3 subunit. (C) $2 \mu \mathrm{M}$ mastoparan was included or not (control) in the incubation medium. (D) Golgi membranes were preincubated for $1 \mathrm{~h}$ at $37^{\circ} \mathrm{C}$ with 0 (control), $0.1,0.5$ or $1 \mu \mathrm{g} / \mathrm{ml}$ of each one cholera toxin (Chl) or pertussis toxin (Ptx) diluted in assay buffer. Alternatively, they were treated with both toxins simultaneously. They were reisolated, rinsed, and incubated in the standard incubation medium. Bound RII $\alpha$ was quantitated and expressed as percentage of the amount incorporated under control conditions. induced a significant, 3-4-fold increase in RII $\alpha$ recruitment (Fig. 9B). The $\mathrm{G} \alpha_{\mathrm{i} 3}$ preparation was biologically active as shown by its ability to bind $\left[{ }^{35} \mathrm{~S}\right] \mathrm{GTP} \gamma \mathrm{S}$ (132 pmol GTP $\gamma$ S/nmol protein). Addition to the assay of $2-4 \mu \mathrm{M}$ mastoparan, an amphipathic peptide that activates $G \alpha_{i}$ and $\mathrm{G} \alpha_{\mathrm{o}}$ subunits (Bomsel and Mostov, 1992), also stimulated binding of RII $\alpha$ to the Golgi membranes (Fig. 9C). Furthermore, we made use of Golgi membranes which had been preincubated with bacterial toxins known to catalyze ADP-ribosylation of particular $\mathrm{G} \alpha$ subunits (Bomsel and Mostov, 1992) (Fig. 9D). RII $\alpha$ incorporation was increased following pretreatment of Golgi membranes with cholera toxin which selectively activates Gos. Depending on the toxin concentration and duration of the treatment, either 1 hour or 4 hours, the amount of RII $\alpha$ bound was increased 1.6- to 2.7-fold with respect to control membranes that had not been preincubated with the toxin. By contrast, pretreatment with pertussis toxin decreased RII $\alpha$ binding when low concentrations, $0.1-0.5 \mu \mathrm{g} / \mathrm{ml}$, of the toxin were used whereas at higher concentrations, $1 \mu \mathrm{g} / \mathrm{ml}$, a 1.3 -fold stimulatory effect was observed. Pertussis toxin ADPribosylates a number of $\mathrm{G} \alpha$ proteins including $\mathrm{G} \alpha_{\mathrm{i}}, \mathrm{G} \alpha_{0}$, and $\mathrm{G} \alpha_{t}$ whose differential inactivation could explain these opposite effects (Bomsel and Mostov, 1992). Interestingly, when Golgi membranes were preincubated with both toxins simultaneously RII $\alpha$ recruitment decreased independently of the concentration used (Fig. 9D). Collectively, these data support the involvement of different Golgi-located $\mathrm{G} \alpha$ proteins in the control of PKA recruitment.

\section{cAMP effect}

A different potential factor affecting PKA interaction with the Golgi would be cAMP since each R subunit contains two cAMP-binding sites. In fact, it was shown previously that in response to an increase in cAMP intracellular concentration $\mathrm{C} \alpha$ dissociates from the Golgi and redistributes to the nucleus whereas RII $\alpha$ would remain Golgi-associated (Nigg et al., 1985a). We reasoned that since the above data indicated that RII $\alpha$ is not permanently anchored to the Golgi but cycles between the Golgi and the cytosol binding of cAMP to RII $\alpha$ might also affect recruitment. We therefore analyzed the association of RII $\alpha$ to Golgi membranes in the presence of increasing concentrations of cAMP. RII $\alpha$ recruitment was decreased by 3 -fold with $1 \mu \mathrm{M}$ cAMP with maximal inhibition, 8 - to 10 -fold decrease, taking place at concentrations above 10 $\mu \mathrm{M}$ cAMP (Fig. 10). Since $20 \mu \mathrm{M}$ cAMP is required to fully activate all the RII $\alpha$ molecules present in the assay these results reflect the inhibitory effect caused by the occupancy of the cAMP-binding sites. Thus, binding of cAMP to RII $\alpha$ decreases the ability of this protein to interact with the Golgi membranes.

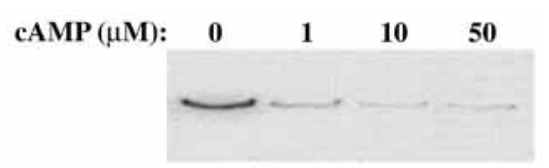

Fig. 10. Effect of cAMP on RII $\alpha$ recruitment. The assay that monitors binding of recombinant RII $\alpha$ to Golgi membranes was supplemented with the indicated concentrations of cAMP. Samples were incubated for 15 minutes at $37^{\circ} \mathrm{C}$ and processed as described in Fig. 6. 


\section{DISCUSSION}

\section{PKAll localization within the Golgi}

We have previously shown that PKA enzymatic activity regulates membrane protein transport along the secretory pathway (Muñiz et al., 1996) and it is required for the formation of constitutive transport vesicles from the transGolgi network (Muñiz et al., 1997). The ultrastructural localization of PKAII subunits is consistent with such a role. Both the cis- and trans-Golgi networks were shown to be major subcellular locations of PKAII anchoring by immunogold labeling (Fig. 3). In contrast, medial-Golgi cisternae showed little labeling if any (Table 1). The mechanism of protein transport across the Golgi complex, whether mediated by vesicles/tubules or taking place by cisternal maturation, is controversial at present (Mironov et al., 1997; Farquhar and Palade, 1998). It is well established, however, that transfer of proteins and lipids between the endoplasmic reticulum and the Golgi as well as export from the Golgi requires cargo selection and packing within some kind of membrane-bound carrier intermediates (Schekman and Orci, 1996; Bannykh and Balch, 1997). The trans-Golgi network is the departure site for soluble and membrane proteins whose final destination is the plasma membrane, the extracellular space or endosomes and lysosomes (Traub and Kornfeld, 1997). The cis-Golgi network, on the other hand, receives molecules from the endoplasmic reticulum and selects those to be returned back to the endoplasmic reticulum by retrograde transport (Aridor and Balch, 1996). The fact that PKAII is concentrated at both the entrance and exit sites of the Golgi stack emphasizes the importance of this kinase in the control of transport activities. PKA could be involved in an initial step in the formation of transport intermediates such as coat assembly and/or cargo selection. Other kinases like protein kinase C (Simon et al., 1996), tyrosine kinase (Austin and Shields, 1996) and phosphatidylinositol-3-kinase (Jones and Howell, 1997) might also participate in this highly regulated process.

\section{PKAll association/dissociation cycle}

Cells incubated with BFA (Figs 1B, 4) or at low temperature (Figs 1B, 7) showed redistribution of PKAII subunits from the Golgi to the cytosol. This suggests that Golgi association is not permanent but instead PKAII would continuously cycle between the cytosol and the Golgi. Data obtained in vitro support this conclusion. Interaction of recombinant RII $\alpha$ subunit with Golgi membranes did not occur at low temperature whereas it was not affected by the presence of BFA in the assay medium (Fig. 6). Both effects can be explained if in cells incubated with BFA or exposed at low temperature RII $\alpha$ can dissociate from the Golgi membranes but it is unable to reassociate with them. In the case of BFA this would be due to the alteration induced by this agent in the organization of the Golgi complex (Klausner et al., 1992). It was shown previously that in response to an increase in cAMP intracellular concentration $\mathrm{C} \alpha$ dissociates from the Golgi and redistributes to the nucleus whereas RII $\alpha$ would remain Golgiassociated (Nigg et al., 1985a). Our data, however, suggest that association of RII $\alpha$ with the Golgi membranes is transient as well. In fact, RII $\alpha$ has been described recently to become dissociated from the Golgi during mitosis (Keryer et al., 1998). While in this study the relationship between $\mathrm{RII} \alpha$ dissociation and the fragmentation undergone by the Golgi complex during mitosis was not addressed the data reported here indicate that both PKAII subunits continuously associate and dissociate from the intact Golgi complex of interphase cells.

We envisage a scenario in which the complete PKAII holoenzyme would be recruited from the cytosol. Interaction with the Golgi would involve the RII $\alpha$ subunits and an AKAP protein localized in the Golgi membranes. Our data indicate that this acceptor molecule is resistant to treatment with high salt and therefore would be an integral membrane protein. The Golgi-associated RII $\beta$-binding protein identified previously was also described as an integral membrane protein (Rios et al., 1992). We are tempted to speculate that during the budding process a local increase in cAMP concentration would occur at the cytosolic side of the Golgi membrane. Binding of cAMP to the RII $\alpha$ subunits would promote activation of Golgi-bound PKAII. The released $\mathrm{C} \alpha$ subunits would then be able to phosphorylate particular Golgi proteins that somehow would trigger membrane evagination. This would explain the stimulatory effect of adding free exogenous $\mathrm{C} \alpha$ subunits to an in vitro budding assay (Muñiz et al., 1997). The dimer formed by the two RII $\alpha$ subunits and containing cAMP bound would also become dissociated from the Golgi as suggestted by the effect of cAMP on RII $\alpha$ recruitment (Fig. 10). In this model, the RII $\alpha$ subunits would funtion to bring the $\mathrm{C} \alpha$ subunits close to the sites of bud formation in the Golgi membrane. To test the model it will be necessary to prove that PKAII recruitment from cytosol indeed precedes budding of transport intermediates.

\section{Regulation by trimeric $\mathrm{G}$ proteins}

Incubation of intact cells with $\mathrm{AlF}_{4}{ }^{-}$gave rise to $\mathrm{RII} \alpha$ redistribution from the Golgi to the cytosol (Figs 1B, 8A). While GTP $\gamma \mathrm{S}$ activates both trimeric and low-molecular-mass GTP-binding proteins $\mathrm{AlF}_{4}^{-}$primarily activates trimeric $\mathrm{G}$ proteins (Kahn, 1991; Bomsel and Mostov, 1992). Although activation of certain classes of small GTP-binding proteins with $\mathrm{AlF}_{4}{ }^{-}$has been reported (Mittal et al., 1996; Reza et al., 1997; Hoffman et al., 1998) additional results obtained in vitro

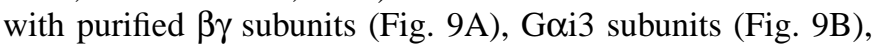
mastoparan (Fig. 9C), and bacterial toxins (Fig. 9C) support the involvement of trimeric $G$ proteins in the regulation of PKAII recruitment.

Whereas the available data are consistent with trimeric $G$ proteins controlling PKAII recruitment from cytosol it is unclear at present the role played by particular $\mathrm{G} \alpha$ subunits in the process. From the effects caused by general modulators it can be inferred a negative regulatory role of trimeric $G$ proteins on RII $\alpha$ incorporation. Thus, $G$ proteins activation with either GTP $\gamma \mathrm{S}$ or $\mathrm{AlF}_{4}^{-}$inhibited RII $\alpha$ recruitment whereas it was stimulated by addition of $\beta \gamma$ subunits which should be able to complex with free $\mathrm{G} \alpha$ subunits and therefore would cause $\mathrm{G}$ proteins inactivation (Fig. 9A). However, RII $\alpha$ recruitment was increased (3-fold at $10 \mathrm{nM}$ ) by addition of a recombinant, myristoylated form of $\mathrm{G}_{\mathrm{i} 3}$ (Fig. 9B). This protein could bind $\left[{ }^{35} \mathrm{~S}\right] \mathrm{GTP} \gamma \mathrm{S}$ and therefore was functionally active. Incorporation of RII $\alpha$ was also increased by the peptide mastoparan (Fig. 9C), which mimics the cytoplasmic domain of an activated receptor giving rise to the activation of $G \alpha_{i}$ and

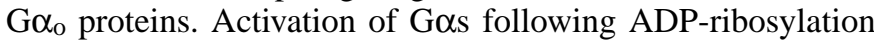
with cholera toxin also stimulated RII $\alpha$ binding (Fig. 9D). 
Therefore, it seems that different $\mathrm{G} \alpha$ proteins with opposite effects would be involved in RII $\alpha$ recruitment.

In recent years the involvement of heterotrimeric $G$ proteins in the control of both Golgi structural organization (Hidalgo et al., 1995; Jamora et al., 1997; Yamaguchi et al., 1997) and transport activities (Stow et al., 1991; Bomsel and Mostov, 1992; Colombo et al., 1992; Leyte et al., 1992; Schwaninger et al., 1992; Pimplikar and Simons, 1993; Helms et al., 1998) has been examined in detail. Several $\mathrm{G} \alpha$ subunits including Gos (Denker et al., 1996), XL $\alpha$ s (Kehlenbach et al., 1994), $\mathrm{G} \alpha_{\mathrm{i} 2}$ (Montmayeur and Borrelli, 1994), $\mathrm{G} \alpha_{\mathrm{i} 3}$ (Stow et al., 1991; Denker et al., 1996), and $\mathrm{G \alpha}_{\mathrm{q} / 11}$ (Denker et al., 1996) have been characterized as Golgi residents but yet their mechanism of action remains unclear. $\mathrm{AlF}_{4}{ }^{-}$inhibits intraGolgi transport in vitro by blocking the fusion of COPI-coated vesicles with acceptor membranes (Melançon et al., 1987; Helms et al., 1998). However, other data have implicated G $\alpha$ proteins in coat assembly and thereby vesicle formation. Excess of $\beta \gamma$ subunits inhibited association with the Golgi membranes of ADP-ribosylation factor (ARF) and $\beta$-COP (Donaldson et al., 1991). Mastoparan promoted $\beta$-COP binding to Golgi membranes and antagonized the effect of BFA (Ktistakis et al., 1992). Moreover, different $\mathrm{G} \alpha$ proteins with opposite effects seem to act coordinately to control protein export from the trans-Golgi network (Leyte et al., 1992; Pimplikar and Simons, 1993) and the endoplasmic reticulum (Schwaninger et al., 1992). The finding that recruitment of RII $\alpha$ is regulated by $G \alpha$ proteins present in the Golgi membranes implies that at least some of the processes controlled by these signaling molecules are PKA-mediated. In fact, evidences have been obtained of membrane traffic events that are regulated by $\mathrm{G} \alpha$ proteins through a mechanism that involves both cAMP and PKA (Hansen and Casanova, 1994; Valenti et al., 1998). Trimeric G proteins, PKA, and AKAP could then be part of a signaling pathway located at the Golgi membranes and destined to control Golgi structural integrity and function.

We thank Drs Hans-Peter Hauri, Michel Bornens, S. Fuller, YeeKin Ho, and Susan S. Taylor for providing reagents necessary for this study. Supported by grant 97/1170 from the Spanish Fondo de Investigación Sanitaria.

\section{REFERENCES}

Aridor, M. and Balch, W. E. (1996). Principles of selective transport: coat complexes hold the key. Trends Cell Biol. 6, 315-320.

Austin, C. D. and Shields, D. (1996). Formation of nascent secretory vesicles from the trans-Golgi network of endocrine cells is inhibited by tyrosine kinase and phosphatase inhibitors. J. Cell Biol. 135, 1471-1483.

Bailly, E., Dorée, M., Nurse, P. and Bornens, M. (1989). p34 $4^{\text {cdc2 }}$ is located in both nucleus and cytoplasm; part is centrosomally associated at $\mathrm{G}_{2} / \mathrm{M}$ and enters vesicles at anaphase. EMBO J. 8, 3985-3995.

Bannykh, S. I. and Balch, W. E. (1997). Membrane dynamics at the endoplasmic reticulum-Golgi interface. J. Cell Biol. 138, 1-4.

Bomsel, M. and Mostov, K. (1992). Role of heterotrimeric G proteins in membrane traffic. Mol. Biol. Cell 3, 1317-1328.

Bradbury, N. A. and Bridges, R. J. (1992). Endocytosis is regulated by protein kinase $\mathrm{A}$, but not protein kinase $\mathrm{C}$ in a secretory epithelial cell line. Biochem. Biophys. Res. Commun. 184, 1173-1180.

Cheng, X., Ma, Y., Moore, M., Hemmings, B. A. and Taylor, S. S. (1998). Phosphorylation and activation of cAMP-dependent protein kinase by phosphoinositide-dependent protein kinase. Proc. Nat. Acad. Sci. USA 95, 9849-9854.
Colledge, M. and Scott, J. D. (1999). AKAPs: from structure to function. Trends Cell Biol. 9, 216-221.

Colombo, M. I., Mayorga, L. S., Casey, P. J. and Stahl, P. D. (1992). Evidence of a role for heterotrimeric GTP-binding proteins in endosome fusion. Science 255, 1695-1697.

De Camilli, P., Moretti, M., Donini, S. D., Walter, U. and Lohmann, S. M. (1986). Heterogeneous distribution of the cAMP receptor protein RII in the nervous system: evidence for its intracellular accumulation on microtubules, microtubule-organizing centers, and in the area of the Golgi complex. J. Cell Biol. 103, 189-203.

Dell'Acqua, M. L. and Scott, J. D. (1997). Protein kinase A anchoring. $J$. Biol. Chem. 272, 12881-12884.

Denker, S. P., McCaffrey, J. M., Palade, G. E., Insel, P. A. and Farquhar, M. G. (1996). Differential distribution of $\alpha$ subunits and $\beta \gamma$ subunits of heterotrimeric $\mathrm{G}$ proteins on Golgi membranes of the exocrine pancreas. $J$. Cell Biol. 133, 1027-1040.

Dohrman, D. P., Diamond, I. and Gordon, A. S. (1996). Ethanol causes translocation of cAMP-dependent protein kinase catalytic subunit to the nucleus. Proc. Nat. Acad. Sci. USA 93, 10217-10221.

Donaldson, J. G., Kahn, R. A., Lippincott-Schwartz, J. and Klausner, R. D. (1991). Binding of ARF and $\beta$-COP to Golgi membranes: possible regulation by a trimeric G protein. Science $\mathbf{2 5 4}$, 1197-1199.

Eker, P., Holm, P. K., Deurs, B. v. and Sandvig, K. (1994). Selective regulation of apical endocytosis in polarized Madin-Darby canine kidney cells by mastoparan and cAMP. J. Biol. Chem. 1994, 18607-18615.

Farquhar, M. G. and Palade, G. E. (1998). The Golgi apparatus: 100 years of progress and controversy. Trends Cell Biol. 8, 2-10.

Feliciello, A., Giuliano, P., Porcellini, A., Garbi, C., Obici, S., Mele, E., Angotti, E., Grieco, D., Amabile, G., Cassano, S., Li, Y., Musti, A. M., Rubin, C. S., Gottesman, M. E. and Avvedimento, E. V. (1996). The v$\mathrm{Ki}$-Ras oncogene alters cAMP nuclear signaling by regulating the location and expression of cAMP-dependent protein kinase II $\beta$. J. Biol. Chem. 271, 25350-25359.

Goretzki, L. and Mueller, B. M. (1997). Receptor-mediated endocytosis of urokinase-type plasminogen activator is regulated by cAMP-dependen protein kinase. J. Cell Sci. 110, 1395-1402.

Griffiths, G., Hollinshead, R., Hemmings, B. A. and Nigg, E. A. (1990). Ultrastructural localization of the regulatory (RII) subunit of cyclic AMPdependent protein kinase to subcellular compartments active in endocytosis and recycling of membrane receptors. J. Cell Sci. 1990, 691-703.

Hansen, S. H. and Casanova, J. E. (1994). Gs $\alpha$ stimulates transcytosis and apical secretion in MDCK cells through cAMP and protein kinase A. J. Cell Biol. 126, 677-687.

Helms, J. B., Helms-Brons, D., Brügger, B., Gkantiragas, I., Eberle, H., Nickel, W., Nürnberg, B., Gerdes, H.-H. and Wieland, F. T. (1998). A putative heterotrimeric $\mathrm{G}$ protein inhibits the fusion of COPI-coated vesicles. J. Biol. Chem. 273, 15203-15208.

Hidalgo, J., Muñiz, M. and Velasco, A. (1995). Trimeric G proteins regulate the cytosol-induced redistribution of Golgi enzymes into the endoplasmic reticulum. J. Cell Sci. 108, 1805-1815.

Hoffman, G. R., Nassar, N., Oswald, R. E. and Cerione, R. A. (1998) Fluoride activation of the rho family GTP-binding protein Cdc42Hs. J. Biol. Chem. 273, 4392-4399.

Jamora, C., Takizawa, P. A., Zaarour, R. F., Denesvre, C., Faulkner, D. J. and Malhotra, V. (1997). Regulation of Golgi structure through heterotrimeric G proteins. Cell 91, 617-626.

Jilling, T. and Kirk, K. L. (1996). Cyclic AMP and chloride-dependent regulation of the apical constitutive secretory pathway in colonic epithelial cells. J. Biol. Chem. 271, 4381-4387.

Jones, S. M. and Howell, K. E. (1997). Phosphatidylinositol 3-kinase is required for the formation of constitutive transport vesicles from the TGN J. Cell Biol. 139, 339-349.

Kahn, R. A. (1991). Fluoride is not an activator of the smaller (20-25 kDa) GTP-binding proteins. J. Biol. Chem. 266, 15595-15597.

Kehlenbach, R. H., Matthey, J. and Huttner, W. B. (1994). XL $\alpha$ s is a new type of G protein. Nature 372, 804-809.

Keryer, G., Yassenko, M., Labbé, J.-C., Castro, A., Lohmann, S. M., Evain-Brion, D. and Taskén, K. (1998). Mitosis-specific phosphorylation and subcellular redistribution of the RII $\alpha$ regulatory subunit of cAMPdependent protein kinase. J. Biol. Chem. 273, 34594-34602.

Klausner, R. D., Donaldson, J. G. and Lippincott-Schwartz, J. (1992). Brefeldin A: insights into the control of membrane traffic and organelle structure. J. Cell Biol. 1992, 1071-1080.

Ktistakis, N. T., Linder, M. E. and Roth, M. G. (1992). Action of brefeldin 
A blocked by activation of a pertussis-toxin-sensitive G protein. Nature $\mathbf{3 5 6}$, 344-346.

Laemmli, U. K. (1970). Cleavage of structural proteins during the assembly of the head of bacteriophage T4. Nature 227, 680-685.

Leyte, A., Barr, F. A., Kehlenbach, R. H. and Huttner, W. B. (1992). Multiple trimeric G-proteins on the trans-Golgi network exert stimulatory and inhibitory effects on secretory vesicle formation. EMBO J. 11, 47954804.

Linstedt, A. D. and Hauri, H.-P. (1993). Giantin, a novel conserved Golgi membrane protein containing a cytoplasmic domain of at least $350 \mathrm{kDa}$. Mol. Biol. Cell 4, 679-693.

Melançon, P., Glick, B. S., Malhotra, V., Weidman, P. J., Serafini, T., Gleason, M. L., Orci, L. and Rothman, J. E. (1987). Involvement of GTPbinding ' $G$ ' proteins in transport through the Golgi stack. Cell 51, 10531062.

Mironov, A. A., Weidman, P. and Luini, A. (1997). Variations on the intracellular transport theme: maturing cisternae and trafficking tubules. $J$. Cell Biol. 138, 481-484.

Mittal, R., Ahmadian, M. R., Goody, R. S. and Wittinghofer, A. (1996). Formation of a transition-state analog of the Ras GTPase reaction by RasGDP, tetrafluoroaluminate, and GTPase-activating proteins. Science 273, 115-117.

Montmayeur, J.-P. and Borrelli, E. (1994). Targeting of Gai2 to the Golgi by alternative spliced carboxyl-terminal region. Science 263, 95-98.

Mostov, K. E. and Cardone, M. H. (1995). Regulation of protein traffic in polarized epithelial cells. BioEssays 17, 129-138.

Muñiz, M., Alonso, M., Hidalgo, J. and Velasco, A. (1996). A regulatory role for cAMP-dependent protein kinase in protein traffic along the exocytic route. J. Biol. Chem. 271, 30935-30941.

Muñiz, M., Martín, M. E., Hidalgo, J. and Velasco, A. (1997). Protein kinase A activity is required for the budding of constitutive transport vesicles from the trans-Golgi network. Proc. Nat. Acad. Sci. USA 94, 14461-14466.

Nigg, E. A., Hilz, H., Eppenberger, H. M. and Dutly, F. (1985a). Rapid and reversible translocation of the catalytic subunit of cAMP-dependent protein kinase type II from the Golgi complex to the nucleus. EMBO J. 4, 28012806.

Nigg, E. A., Schäfer, G., Hiltz, H. and Eppenberger, H. M. (1985b). CyclicAMP-dependent protein kinase type II is associated with the Golgi complex and with centrosomes. Cell 41, 1039-1051.

Pawson, T. and Scott, J. D. (1997). Signaling through scaffold, anchoring, and adaptor proteins. Science 278, 2075-2080.

Pimplikar, S. W. and Simons, K. (1993). Regulation of apical transport in epithelial cells by a Gs class of heterotrimeric G protein. Nature 362, 456458 .
Pimplikar, S. W. and Simons, K. (1994). Activators of protein kinase A stimulate apical but not basolateral transport in epithelial Madin-Darby canine kidney cells. J. Biol. Chem. 269, 19054-19059.

Reza, M., Mittal, R., Hall, A. and Wittinghofer, A. (1997). Aluminum fluoride associates with the small guanine nucleotide binding proteins. FEBS Lett 408, 315-318.

Rios, R. M., Celati, C., Lohmann, S. M., Bornens, M. and Keryer, G. (1992). Identification of a high affinity binding protein for the regulatory subunit RII $\beta$ of cAMP-dependent protein kinase in Golgi enriched membranes of human lymphoblasts. EMBO J. 11, 1723-1731.

Schekman, R. and Orci, L. (1996). Coat proteins and vesicle budding. Science 271, 1526-1533.

Schwaninger, R., Plutner, H., Bokoch, G. M. and Balch, W. E. (1992). Multiple GTP-binding proteins regulate vesicular transport from the ER to Golgi membranes. J. Cell Biol. 1992, 1077-1096.

Simon, J.-P., Ivanov, I. E., Adesnik, M. and Sabatini, D. D. (1996). The production of post-Golgi vesicles requires a protein kinase C-like molecule, but not its phosphorylating activity. J. Cell Biol. 135, 355-370.

Slot, J. W. and Geuze, H. J. (1985). A new method of preparing gold probes for multiple-labeling cytochemistry. Eur. J. Cell Biol. 38, 87-93.

Slusarewicz, P., Nilsson, T., Hui, N., Watson, R. and Warren, G. (1994) Isolation of a matrix that binds medial Golgi enzymes. J. Cell Biol. 124, 405-413.

Stow, J. L., Almeida, J. B., Narula, N., Holtzman, E. J., Ercolani, L. and Ausiello, D. A. (1991). A hetrotrimeric G protein, G $\alpha i-3$, on Golgi membranes regulates the secretion of a heparan sulfate proteoglycan in LLC-PK1 epithelial cells. J. Cell Biol. 114, 1113-1124.

Taylor, S. S., Buechler, J. A. and Yonemoto, W. (1990). cAMP-dependent protein kinase: framework for a diverse family of regulatory enzymes. Annu. Rev. Biochem. 59, 971-1005.

Traub, L. M. and Kornfeld, S. (1997). The trans-Golgi network: a late secretory sorting station. Curr. Opin. Cell Biol. 9, 527-533.

Valenti, G., Procino, G., Liebenhoff, U., Frigeri, A., Benedetti, P. A., Ahnert-Hilger, G., Nürnberg, B., Svelto, M. and Rosenthal, W. (1998). A heterotrimeric $\mathrm{G}$ protein of the Gi family is required for cAMP-triggered trafficking of aquaporin 2 in kidney epithelial cells. J. Biol. Chem. 273, 22627-22634

Yamaguchi, T., Yamamoto, A., Furuno, A., Hatsuzawa, K., Tani, K., Himeno, M. and Tagaya, M. (1997). Possible involvement of heterotrimeric $\mathrm{G}$ proteins in the organization of the Golgi apparatus. J. Biol. Chem. 272, 25260-25266.

Zegers, M. M. P. and Hoekstra, D. (1997). Sphingolipid transport to the apical plasma membrane domain in human hepatoma cells is controlled by PKC and PKA activity: a correlation with cell polarity in HepG2 cells. $J$. Cell Biol. 138, 307-321. 